\title{
Impact of thermal renovation on selected characteristics of partition walls and the consumption of heat energy
}

\author{
Krzysztof Cieśliński \\ (1) http://orcid.org/0000-0002-6789-6193 \\ Łomża Housing Cooperative \\ Urszula Malaga-Tobota \\ umalagatobola@gmail.com | @ http://orcid.org /0000-0001-7918-8699 \\ University of Agriculture in Krakow, Faculty of Production and Power \\ Engineering
}

Scientific Editor: Andrzej Winnicki, Cracow University of Technology Technical Editor: Aleksandra Urzędowska, Cracow University of Technology Press Language Editor: Tim Churcher, Big Picture Typesetting: Matgorzata Murat-Drożyńska, Cracow University of Technology Press

Received: July 22, 2021

Accepted: October 20, 2021

\begin{abstract}
Copyright: @ 2021 Cieśliński, Malaga-Tobota. This is an open access article distributed under the terms of the Creative Commons Attribution License, which permits unrestricted use, distribution, and reproduction in any medium, provided the original author and source are credited.
\end{abstract}

Data Availability Statement: All relevant data are within the paper and its Supporting Information files.

Competing interests: The authors have declared that no competing interests exist.

Citation: Cieśliński, K., Malaga-Tobota, U. (2021). Impact of thermal renovation on selected characteristics of partition walls and the consumption of heat energy . Technical Transactions, e2021018. https:// doi.org/10.37705/TechTrans/e2021018

\begin{abstract}
Renovation of multi-family residentials, including mainly thermal renovation, which includes adding thermal insulation, contributes to the improvement of living conditions. Above all, it reduces the operating costs of renovated buildings by reducing the consumption of heat energy for central heating. This article discusses the impact of light wet thermal renovation on the temperature distribution in the vertical cross-section of the partition wall and the calculation value of the temperature on the inner surface of the partition wall, as well as on the reduction of thermal energy consumption in buildings. The subject of the research was residentials erected in the large-panel, large-block, and traditional technology between 1984 and 1994, managed by Łomża Housing Cooperative ( $(S M)$.
\end{abstract}

Keywords: thermal renovation, heat transfer coefficient, temperature distribution, thermal protection of buildings 


\section{INTRODUCTION}

Following the end of World War II, the situation in the housing economy in Poland was particularly difficult. In a way, it triggered the need to accelerate the reconstruction of the country (Konieczny, 1980). Thus, traditional, craft-based construction methods, which included organizing a significant part of production at the construction site, were replaced by industrialized construction. This enabled the dynamic development of the housing sector (Tauszyński, 1997; Wojtkun, 2011). Developed in the first half of the 20th century in Western Europe and Scandinavia (France, Finland, and Sweden), prefabrication appeared in Poland in the early 1950s (Wierzbicki, 1999). At its peak of prosperity, the construction of multi-family residentials by industrialized technology allowed completing a record number of seven million apartments in Poland (Orchowska, 2020). However, the two technologies of industrialized construction that are dominant in Poland often referred to as "the large panel" should be distinguished (Nowak, 1995).

The first is the Plattenbau, or large-panel technology, which according to Ostańska, accounts for as much as $50 \%$ of the total implementation technology in multi-family housing in the years 1946-1992 (Ostańska, 2014). In this system, ceilings and walls form large-size elements that usually correspond to the internal division into rooms or their groups (Ickiewicz, 2018; Wtodarczyk, 2013). On the other hand, $24 \%$ of buildings erected in Poland in the years 19461992 were made in a large-block technology. It differs from the Plattenbau in that the division of partitions constituting walls is not related to the division of the interior into individual rooms, and the partition wall of one room may consist of several blocks (Niedostatkiewicz, 2009; Ostańska, 2014; Tauszyński, 1997).

For many years, buildings made in large-panel and large-block technology have been the object of interest of both science and property managers. The expected 50-year operation period certainly contributed to this. This view has been unequivocally undermined by the results of research, e.g., by the Building Research Institute in Poland, as well as other authors (Ostańska, 2016; Runkiewicz et al., 2014). Because of the many disadvantages and shortcomings of the systems, buildings made with these technologies require constant technical supervision and modernization of, first of all, basic structural elements, e.g., external walls (Gronostajska, 2010; Janczarek et al., 2006; Lewicki, 2000). The characteristic feature of large-panel and large-block objects is their low thermal insulation (Bajno and Grzybowska, 2017; Taczanowska and Ostańska, 2012). Seasonal demand for thermal energy to heat prefabricated buildings built in the peak of industrial construction of the People's Republic of Poland is usually 50 to $100 \%$ higher than the applicable requirements expressed by the $\mathrm{E}$ coefficient (Ostańska, 2010; Radoń and Künzel, 2006). The crisis in the fuel sector in the 1970s initiated the trend to conserve conventional energy sources. Taking into account that the construction industry consumes approx. $40 \%$ of the total amount of energy produced, many countries have initiated measures to reduce the energy consumption of the entire economy, including the housing sector (Szul, 2016). The ever-growing prices of thermal energy brought about an interest in thermal renovation investments that would optimize its consumption (Obolewicz and Tomaszewicz, 2016). Their intended effect is to reduce the energy demand, but also to lower the costs of its production. The key factor here is also the introduction of far-reaching energy constraints, following Poland's membership in the European Union (Szul, 2016; Szul, 2012). They are to be applied already at the project stage of the building's construction and include both the buildings that are only under construction, as well as the existing ones intended for thermal renovation (Dohojda and Wiśniewski, 2019). The constraints also apply to the requirements for the permissible level of emission of air pollutants generated during the combustion of fuels in the energy generation process (Ickiewicz, 2018).

The study aimed to compare the impact of thermal renovation on the value of computational temperature on the inner surface of the wall, on the temperature distribution in the vertical cross-section of individual layers of partition walls, as 
Fig. 1. Diagram of the OWT-67N large-panel technology curtain wall of the building before (a) and after (b) thermal renovation (own study)
Fig. 2. Diagram of a traditional technology curtain wall before (a) and after (b) thermal renovation (own study)

Fig. 3. Diagram of a large-block technology curtain wall before (a) and after (b) thermal renovation (own study) well as on reducing thermal energy consumption with buildings made in largepanel, large-block, and traditional technologies.

\section{MATERIAL AND METHODS}

The curtain walls of multi-family residentials located in the $4^{\text {th }}$ climate zone, erected in three different technologies, were analyzed. Their basic parameters are presented in Table 1, and the diagrams of the partition walls before and after thermal renovation are presented in Figures 1, 2, and 3.

Table 1. Basic parameters of the analyzed buildings

\begin{tabular}{|c|c|c|c|c|c|}
\hline \multirow{2}{*}{ No. } & Handover & Production technology & Floor area & $\begin{array}{c}\text { Thermal } \\
\text { renovation }\end{array}$ & $\begin{array}{c}\text { Thermal } \\
\text { insulation } \\
\text { method }\end{array}$ \\
\cline { 2 - 6 } & {$[y e a r]$} & {$[-]$} & {$\left[\mathrm{m}^{3}\right]$} & {$[$ year] } & {$[-]$} \\
\hline 1 & 1984 & large-plate OWT-67N & 9876.20 & 2007 & Light wet \\
\hline 2 & 1992 & traditional & 10294.00 & 2015 & Light wet \\
\hline 3 & 1994 & large-block “Żerań brick" & 18376.00 & 2014 & Light wet \\
\hline
\end{tabular}

a)

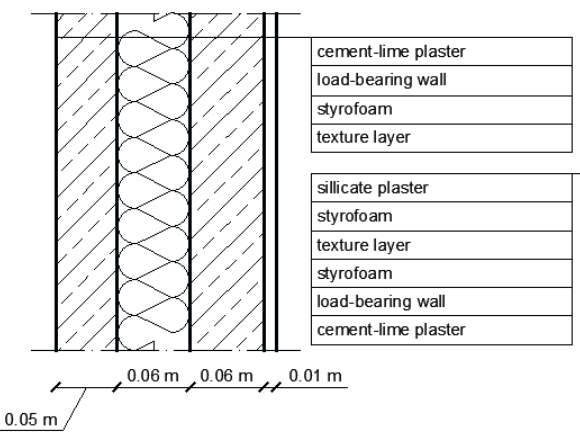

a)

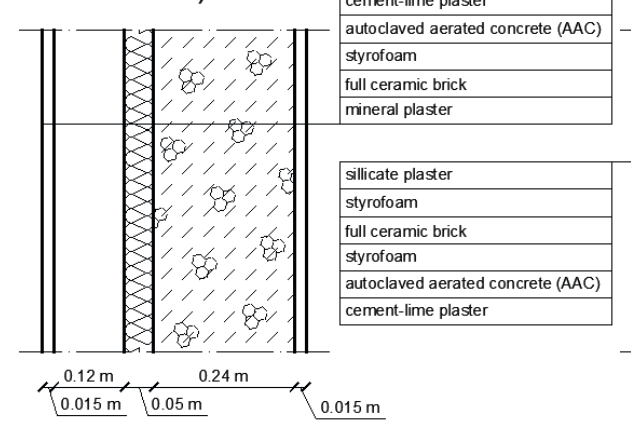

a)

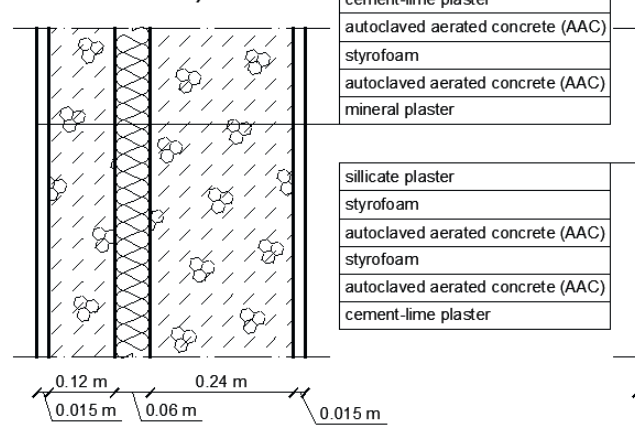

b)

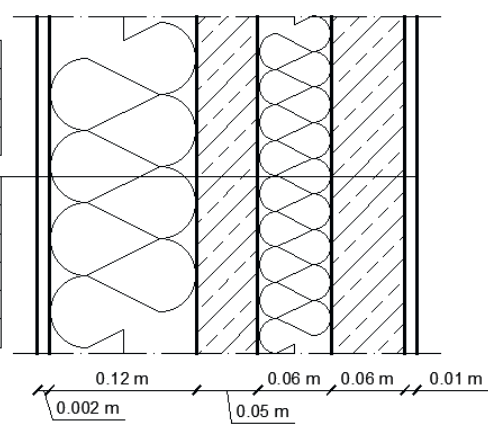

b)

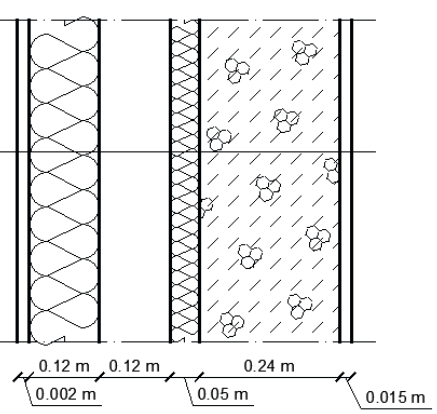

b)

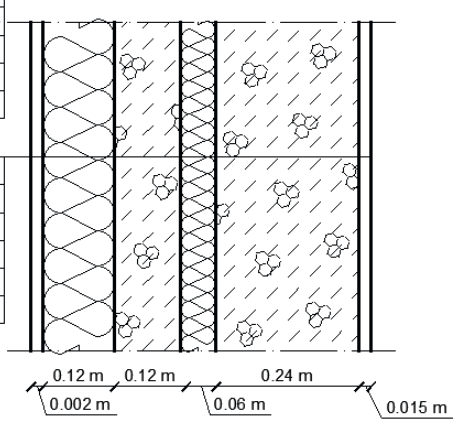


The computational temperature of the internal surface of the partition wall in areas not directly adjacent to the impact zones of linear thermal bridges was calculated from the formula:

$$
v_{t}=t_{i}-U_{C}\left(t_{i}-t_{e}\right) R_{i}\left[{ }^{\circ} \mathrm{C}\right]
$$

where:

$U_{C}$ - heat transfer coefficient, $\mathrm{W} \cdot \mathrm{m}^{-2} \cdot \mathrm{K}^{-1}$;

$t_{e}$ - computational temperature of outdoor air, ${ }^{\circ} \mathrm{C}$;

$t_{i}$ - computational temperature of indoor air, ${ }^{\circ} \mathrm{C}$;

$R_{i}$ - computational heat transfer resistance on the inner surface of the partition wall, with a constant value of $0.167 \mathrm{~m}^{2} \cdot \mathrm{K} \cdot \mathrm{W}^{-1}$, regardless of the direction of heat flow.

The density of the heat flux through a specific partition wall was determined from the formula:

$$
q=U_{0}\left(t_{i}-t_{e}\right)\left[\mathrm{W} \cdot \mathrm{m}^{2-1}\right]
$$

where:

$U_{0}$ - heat transfer coefficient, a value not taking into account the heterogeneity of the layers and the impact of thermal bridges, $\mathrm{W} \cdot \mathrm{m}^{-2} \cdot \mathrm{K}^{-1}$

$t_{i}$ - indoor air (environment) temperature, ${ }^{\circ} \mathrm{C}$;

$t_{e}$ - outdoor air (environment) temperature, ${ }^{\circ} \mathrm{C}$;

As a result of the heat flux at $q$ temperature drops occur on individual layers of the partition wall as the product of the heat flux density and the value of thermal resistance. On the inner surface of the partition wall, the temperature drop will be $q R_{s i}$ due to the heat transfer resistance $R_{s i}$, hence the temperature of the inner surface will be expressed by the formula:

$$
v_{1}=t_{i}-q R_{s i}=t_{i}-U_{0} R_{s i}\left(t_{i}-t_{e}\right)\left[{ }^{\circ} \mathrm{C}\right]
$$

- to calculate heat loss and for computational partition wall characteristics, the usual formula is $R_{s i}=0.13 \mathrm{~m}^{2} \cdot \mathrm{K} \cdot \mathrm{W}^{-1}$,

- to verify the possibility of condensation on the surface of the partitions, the usual formula is $R_{s i}=0.25 \mathrm{~m}^{2} \cdot \mathrm{K} \cdot \mathrm{W}^{-1}$.

At the joint of the first and second layer of the partition wall, the formula is:

$$
v_{2}=t_{i}-U_{0}\left(R_{s i}+R_{1}\right)\left(t_{i}-t_{e}\right)\left[{ }^{\circ} \mathrm{C}\right]
$$

At the joint of the second and third layer:

$$
v_{2}=t_{i}-U_{0}\left(R_{s i}+R_{1}+R_{2}\right)\left(t_{i}-t_{e}\right)\left[{ }^{\circ} \mathrm{C}\right]
$$

Finally, the temperature $v_{u, u+1}$ at the joints of each successive material layer, the formula is:

$$
v_{u, u+1}=t_{i}-U_{0}\left(R_{s i}+\sum_{j=1}^{u} R_{j}\right)\left(t_{i}-t_{e}\right)\left[{ }^{\circ} \mathrm{C}\right]
$$

where index $u$ is the consecutive number of the partition wall layer in question, counting from the inside of the wall. 
Fig. 4. Summary of the heat transfer coefficient values for the curtain wall in the analyzed buildings, before and after thermal renovation (own study)
Fig. 5. An increase in the computational temperature on the inner surface of the partition, resulting from the thermal insulation of curtain walls in the analyzed buildings (own study)

\section{RESULTS}

\section{The computational temperature of the inner surface of the partition wall}

The presented calculations were made for curtain walls of the analyzed buildings before and after thermal renovation, for the following data:

- Location: Łomża,

- Climate zone: $I V$,

- Design outdoor temperature: $t_{e}=-22^{\circ} \mathrm{C}$,

- Computational indoor air temperature: $t_{i}=-20^{\circ} \mathrm{C}$,

- Heat transfer coefficient before and after thermal renovation, based on own calculations:

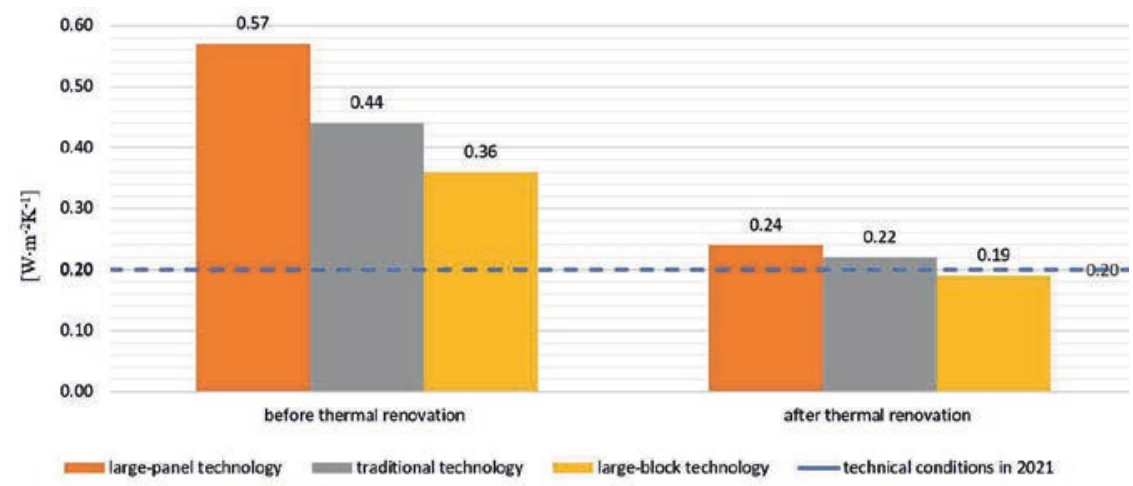

- Computational heat transfer resistance on the inner surface of the partition wall: $R_{i}=0.167 \mathrm{~m}^{2} \cdot \mathrm{K} \cdot \mathrm{W}^{-1}$.

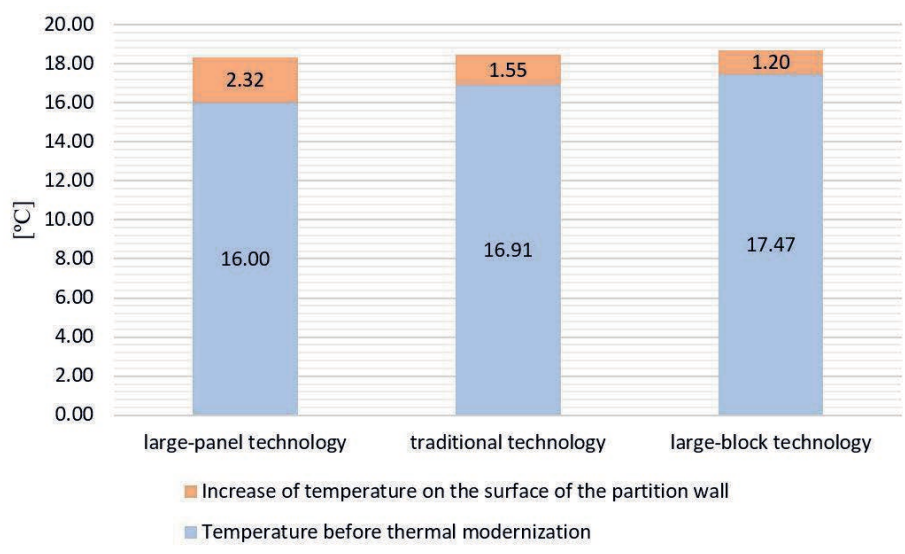

The calculations show that in all analyzed buildings the computational temperature on the internal surface of the partition increased as a result of the thermal renovation. This proves the legitimacy of the renovation measures and directly impacts the comfort of living and the reduction of heat energy consumption for central heating. The highest temperature increases on the inner surface of the partition wall $\left(+2.32^{\circ} \mathrm{C}\right)$, resulting from thermal insulation of the curtain wall, was registered in a building constructed in the OWT-67N large-panel technology. It is related to the most significant decrease of the heat transfer coefficient among the three analyzed objects. As a result of the light wet thermal renovation, this coefficient decreased from 0.57 to $0.24 \mathrm{~W} \cdot \mathrm{m}^{-2} \cdot \mathrm{K}^{-1}$, i.e., by $57.89 \%$. 
The highest temperature on the surface of the partition, after thermal insulation $\left(+18.67^{\circ} \mathrm{C}\right)$, was recorded in a building constructed in large-block technology, the so-called "Żerań brick". As the last one put into operation (1994), this building was characterized by the best thermal insulation properties of the partition walls before thermal renovation. In this case, the heat transfer coefficient before the renovation was $0.36 \mathrm{~W} \cdot \mathrm{m}^{-2} \cdot K^{-1}$ and after $0.19 \mathrm{~W} \cdot \mathrm{m}^{-2} \cdot K^{-1}$, i.e., there was a decrease of $47.22 \%$. The increase in the computational temperature on the inner surface of the curtain wall in this building proved the least significant among all analyzed objects and amounted to $+1.20^{\circ} \mathrm{C}$.

\section{Temperature distribution in the vertical section of the partition wall}

The calculations were made for curtain walls of the analyzed buildings in December, before and after thermal renovation. Data on the values of outdoor temperatures (average monthly dry-bulb temperatures) were obtained from the meteorological station located in the $4^{\text {th }}$ climate zone (Biatystok), using the Purmo OZC Basic 6.7 software. For the month under consideration, the data were as follows:

- Indoor air temperature: $t_{i}=-20.0^{\circ} \mathrm{C}$,

- Outdoor air temperature: $t_{e}=-1.3^{\circ} \mathrm{C}$
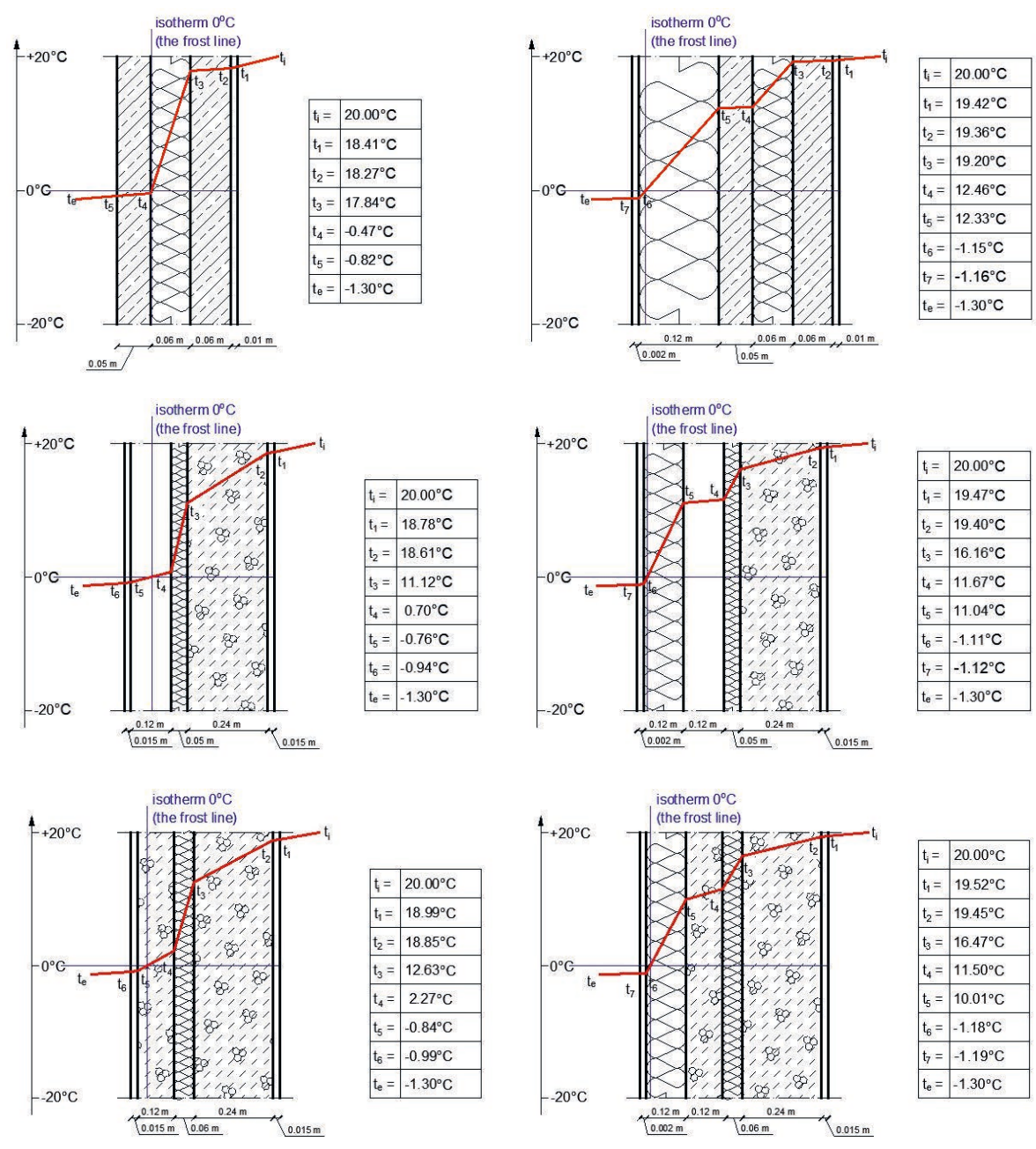

Fig. 6. Temperature distribution in the vertical section of the OWT-67N large-panel technology curtain wall in December, before and after thermal renovation (own study)

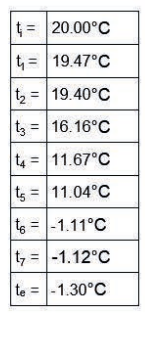

Fig. 7. Temperature distribution in the vertical section of the traditional technology curtain wall in December, before and after thermal renovation (own study)

Fig. 8. Temperature distribution in the vertical section of the large-block technology curtain wall in December, before and after thermal renovation (own study)

Among all analyzed objects, no disturbing phenomena in the temperature distribution in the vertical cross-section of the partition wall were found only in the building made in the large-panel technology. No objections were recorded both before and after the thermal renovation. 
Fig. 9. Average consumption of thermal energy for central heating in the analyzed buildings in the years 2001-2019, before and after thermal renovation (own study)
In the case of a building constructed with traditional and large-block technologies, before the thermal renovation, the temperature distribution graph in the vertical cross-section of the curtain wall revealed the zero isotherm, i.e. the frost line in the outer layers of the partition walls. Please note that the longterm impact of such a phenomenon on the construction material of the wall leads to its corrosion and loss of insulating properties.

In the first case, before the renovation, the curtain wall was made of a sandwich wall consisting of $24 \mathrm{~cm}$ aerated concrete, $5 \mathrm{~cm}$ of polystyrene, and $12 \mathrm{~cm}$ full ceramic brick. As observed from the temperature distribution presented in Fig. 7, freezing occurred in the full ceramic brick layer.

However, in the large-block technology building, the curtain wall before the renovation was made of a partition wall consisting of $24 \mathrm{~cm}$ aerated concrete, $6 \mathrm{~cm}$ polystyrene, and another layer of $12 \mathrm{~cm}$ aerated concrete. Freezing was observed in the last of the above-mentioned layers (Fig. 8).

In both above-mentioned cases, the phenomenon of freezing of external layers of partition walls has been effectively eliminated thanks to the thermal renovation using the seamless thermal insulation method. Adding a $12 \mathrm{~cm}$ layer of polystyrene shifted the frost line to the thermal insulation layer.

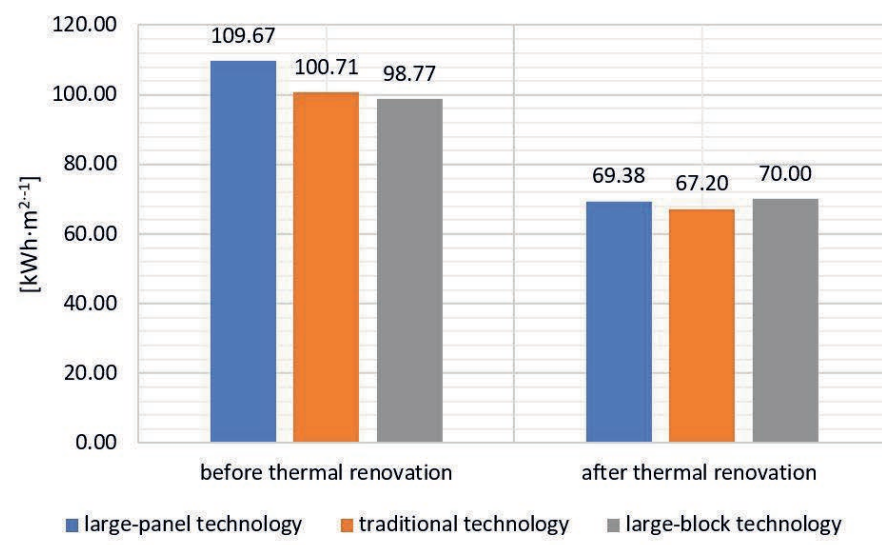

One of the most important criteria for assessing the validity and correctness of the insulation works is the analysis of thermal energy consumption in modernized buildings, taking into consideration the period before and after renovation. Please note that a significant decrease in energy consumption was recorded in all objects when the thermal renovation was completed. In a large-panel building, the average consumption of thermal energy for heating before the thermal renovation was $109.67 \mathrm{kWh} \cdot \mathrm{m}^{2-1}$, and after $-69.38 \mathrm{kWh} \cdot \mathrm{m}^{2-1}$, which proves the consumption reduction by $37.65 \%$. This is the largest reduction in energy consumption among the analyzed objects. On the other hand, with a building made in traditional technology, the average consumption of thermal energy decreased from 100.71 to $67.20 \mathrm{kWh} \cdot \mathrm{m}^{2-1}$, which is a reduction by $33.27 \%$, and in a large-block building from 98.77 to $70.00 \mathrm{kWh} \cdot \mathrm{m}^{2-1}$, which is a reduction by $29.13 \%$. Such a significant reduction in the consumption of thermal energy in the analyzed objects proves the legitimacy of the completed thermal renovation.

\section{CONCLUSION}

The analysis demonstrated that regardless of the technology in which the objects were constructed, the thermal renovation of buildings including, e.g., thermal insulation of external walls, not only reduces the thermal energy consumption for central heating but also improves the thermal protection of the buildings. It also plays a fundamental role in the elimination of undesirable phenomena such 
as freezing of external layers of partition walls, and thus reduces the risk of their degradation in unfavorable weather conditions. Please note that the calculations to verify the temperature value on the internal surface of the partition wall and the temperature distribution in its vertical cross-section were made for the set internal thermal conditions, assuming the temperature $t_{i}$ in the rooms at $20^{\circ} \mathrm{C}$. The daily experiences of property managers, including the Łomża Housing Cooperative, whose buildings were the subject of study, clearly indicate that mold growth is very frequent on the internal surfaces of the walls. This problem results from improper use of the premises during their operation phase. This phenomenon is related to the statutory obligation to settle heat consumption for central heating individually for each apartment, which requires installing central heating cost allocators in apartments. Exaggerated search for savings by the users of the premises leads to excessive cooling of partition walls. Combined with the lack of inflow of fresh air and blocking the outflow of used air by blocking the ventilation grilles creates perfect humidity and thermal conditions for the development of mold. This is confirmed by the annual inspections verifying the technical condition of, e.g., chimney ducts (smoke, exhaust, and ventilation), as stipulated by art. $62 \mathrm{sec}$. 1, point 1c of the Construction Law Act.

\section{REFERENCES}

Bajno, D., Grzybowska, A. (2017). Pozytywne i uboczne skutki prawidtowo wykonanych termomodernizacji obiektów budowlanych na wybranych przyktadach. Przegląd Budowlany, 88(10), 28-33.

Dohojda, M., Wiśniewski, K. (2019). Termomodernizacja sposobem rewitalizacji osiedli mieszkaniowych z wielkiej ptyty. Przegląd Budowlany, 9, 47-50.

Gronostajska, B. (2010). Zespoty mieszkaniowe z wielkiej ptyty w XXI wieku problemy i perspektywy. Architecturae et Artibus, 2, 19-26.

Ickiewicz,I. (2018). Kompleksowatermomodernizacjabudynków wielorodzinnych, a redukcja zanieczyszczenia powietrza na przykładzie miasta w pótnocno-wschodniej Polsce. Fizyka Budowli w Teorii i Praktyce, 10.

Janczarek, M., Skalski, P., Bulyandra, A., Sobczuk, H. (2006). Przewodnośćcieplna zewnętrznych ścian budynków w aspekcie wilgotności i oszczędności energii. Rynek energii, 6, 32-35.

Kłopotowski, M. (1980). OW-T. Betonowy potencjat. Architecturae et Artibus, 1 , 31-38.

Konieczny, Z. (1980). Uprzemystowienie budownictwa mieszkaniowego i mierzenie jego poziomu. Acta Universitatis Lodziensis. Folia Oeconomica, 2.

Lewicki, B. (2000). Rysy w ścianach i stropach budynków wielkoptytowych. Prace Instytutu Techniki Budowlanej, 2-3(114-115), 5-24.

Niedostatkiewicz, M. (2007). Analiza budynków mieszkalnych regionalnego systemu budownictwa wielkoblokowego w aspekcie możliwości ich modernizacji. Zeszyty Naukowe Politechniki Gdańskiej. Budownictwo Lądowe, 61, 203-210.

Nowak, Z. (1995). Struktura budownictwa mieszkaniowego w miastach, zrealizowanego w technologiach uprzemystowionych. Centralny Ośrodek Badawczo-Projektowy Budownictwa Ogólnego, Warszawa. Budownictwo i gospodarka miejska, 3, 11-13.

Obolewicz, J., Tomaszewicz, D. (2016). Problemy modernizacji budynków wielkoptytowych osiedli mieszkaniowych. Inżynieria Bezpieczeństwa Obiektów Antropogenicznych, 1, 31-37.

Orchowska, A. (2020). Rola prefabrykacji w ksztattowaniu architektury mieszkaniowej XXI wieku. Środowisko Mieszkaniowe, 32, 69-80.

Ostańska, A. (2014). Badania struktury zasobów mieszkaniowych w Polsce na przykładzie budynków wznoszonych w technologii prefabrykowanej. Przegląd Budowlany, 85, 24-29. 
Ostańska, A. (2016). Wielka ptyta. Analiza skuteczności podwyższania efektywności energetycznej, Warszawa: WN PWN.

Ostańska, A. (2010). Wpływ dotychczasowych termomodernizacji budynków mieszkalnych na oszczędność energii i planowanie programów rewitalizacji na przyktadzie jednego z lubelskich osiedli. Budownictwo $i$ Architektura, 7(2), 89-103.

Radoń, J., Künzel, H. (2006). Problemy cieplno-wilgotnościowe przy renowacji ścian budynków z muru pruskiego. Acta Scientiarum Polonorum: Architectura, 5 (1), 45-53.

Runkiewicz, L., Szudrowicz, B., Geryło, R., Szulc, J., Sieczkowski, J. (2014). Diagnostyka i modernizacja budynków wielkopłytowych, Część 2. Przegląd Budowlany, 9, 20-26.

Runkiewicz, L., Szulc, J., Sieczkowski, J. (2020). Termomodernizacja budynków wielkoptytowych. Aspekty techniczne i finansowe. Przegląd Budowlany, 91, 20-22.

Szul, T. (2016). Audyt efektywności energetycznej termomodernizacji budynku mieszkalnego jednorodzinnego. Technika Rolnicza Ogrodnicza Leśna, 4, 24-27.

Szul, T. (2012). Charakterystyka energetyczna obiektów oświatowych na przykładzie wybranej gminy powiatu krakowskiego. Technika Rolnicza Ogrodnicza Leśna, 5, ISSN 1732-1719.

Taczanowska, T., Ostańska, A. (2012). Dokładność realizacji a potrzeba modernizacji budynków wielkopłytowych. Dom Wydawniczy MEDIUM.

Tauszyński, K. (1997). Budownictwo z technologią. Cz. I. Podręcznik dla technikum.

Wierzbicki, S.M. (1999). Problemy modernizacji budynków wielkopłytowych, Możliwości techniczne modernizacji budynków wielkopłytowych w Polsce na tle ich aktualnego stanu. Materiaty konferencyjne, Instytut Techniki Budowlanej, 12.

Wtodarczyk, M. (2013). Architektura lat 60. XX wieku. Fragment historii Krakowa i innych polskich miast. Kwartalnik Architektury i Urbanistyki, 58.

Wojtkun, G. (2011). Wielka płyta na styku żelaznej kurtyny. Przestrzeń i Forma, $15,475-484$. 